\title{
GENETIC RESEARCHES AMONG MALAYSIAN FAMILIAL HYPERCHOLESTEROLAEMIC POPULATION
}

\author{
Al-Khateeb $A^{1,2}$, Al-Talib $H^{1}$ \\ 1 Faculty of Medicine, Universiti Teknologi MARA, Jalan Hospital, Sungai Buloh, Selangor, Malaysia. \\ 2 I-PPerForM, Universiti Teknologi MARA, Sungai Buloh Campus, Sungai Buloh, Selangor, Malaysia.
}

\author{
Correspondence: \\ Alyaa R. AL-Khateeb \\ Biochemistry and Molecular Medicine Discipline \\ Faculty of Medicine \\ Universiti Teknologi MARA \\ Selangor, Malaysia \\ Office telephone :+6 61267358 \\ Mobile +6 0129545014 \\ Email:alyaa_1974@yahoo.com
}

\begin{abstract}
Background:

Familial hypercholesterolaemia (FH) is one of the most frequent inherited metabolic disorders that can lead to a risk of premature cardiovascular disease. Publications on $\mathrm{FH}$ are mainly from western patients as there is little research on Asians, including Malaysians. The aim of this review is to provide an up-to- date information on Malaysian studies on FH genotyping and its relation to the phenotype of the affected patients.
\end{abstract}

\section{Method:}

A search was conducted for data from online databases on FH in Malaysia.

\section{Results:}

The mutation spectrum for $\mathrm{FH}$ among Malaysian patients was extremely broad. The gene variants were located mainly in the low-density lipoprotein receptor (LDLR) and apolipoprotein B-100 (APOB-100) genes rather than in the proprotein convertase subtilisin kexin type 9 (PCSK9) gene. The exon 9 and 14 were the hotspots in the LDLR gene. The most frequent mutation was p.Cys $255 \mathrm{Ser}$, at $12.5 \%$, followed by p.Arg $471 \mathrm{Gly}$, at $11 \%$, and the most common single nucleotide polymorphism (SNP) was c. $1060+7 \mathrm{~T}>\mathrm{C}$ at $11.7 \%$. The LDLR gene variants were more common compared to the APOB-100 gene variants, while variants in the PCSK9 gene were very few.

Phenotype-genotype associations were identified. Subjects with LDLR and APOB-100 genes mutations had a higher frequency of cardiovascular disease, a family history of hyperlipidaemia and tendon xanthoma and a higher low-density lipoprotein cholesterol (LDL-C) level than non-carriers.

\section{Conclusion:}

Research on Malaysian familial hypercholesterolaemic patients by individual groups is encouraging. However, more extensive molecular studies on $\mathrm{FH}$ on a national scale, with a screening of the disease-causing mutations together with a comprehensive genotype-phenotype association study, can lead to a better outcome for patients with the disease.

Keywords: apolipoprotein B-100, familial hypercholesterolaemia, low-density lipoprotein receptor, Malaysians, and proprotein convertase subtilisin kexin type 9.

\section{Introduction}

Familial hypercholesterolaemia (FH) is an autosomal dominant inherited disorder in man (1), characterised by an increase in the level of low-density lipoprotein cholesterol (LDL-C), tendon xanthoma (TX) together with an increase in the risk of premature cardiovascular disease (PCVD) 
$(2,3)$. It is the first genetic disorder of lipid metabolism that was characterised both clinically and molecularly (1). Heterozygous $\mathrm{FH}$ is the commonest monogenic disorder, affecting 1 in 200-250 people, which is double what had been reported previously (4). Its penetrance rate is more than $90 \%$ (5). The frequency was reported to be even higher in the Afrikaners, French-Canadians and Christian Lebanese (6), due probably to a founder effect (1). Data from a large community study in Denmark reported that the prevalence of $\mathrm{FH}$ reached up to 1:137 (7). It is believed that there are about 34 million FH patients globally (8) with about 3.6 million in the Asia-Pacific region (9).

Despite the high prevalence of $\mathrm{FH}$ and the considerable advantage of its early detection and treatment, only about $1 \%$ of $\mathrm{FH}$ cases have been diagnosed worldwide (8). There are a few exceptions; in the Netherlands and in Norway, where $71 \%$ and $43 \%$ of patients respectively, with $\mathrm{FH}$, were diagnosed (8). The prevalence of $\mathrm{FH}$ in Malaysia is unknown, and there are no published reports on the systematic analyses of mutations underlying $\mathrm{FH}$.

\section{The most important genes in familial hypercholesterolaemia}

Monogenic FH is mainly attributed to defects in three genes: low-density lipoprotein receptor (LDLR) gene, apolipoprotein B-100 (APOB -100) gene, and proprotein convertase subtilisin kexin type 9 (PCSK9) gene.

The LDLR is a transmembrane protein which is encoded by the LDLR gene. It was first described by Goldstein et al. (10). This gene is located on the short arm of the chromosome 19 at p13.1-p13.3 (11), comprising of 18 exons and 17 introns and spanning 45 kilobases ( $\mathrm{kb}$ ) (12). The LDLR protein is a cell surface receptor and is responsible for the removal of the LDL cholesterol particles from the plasma (13). The uptake of LDL into cells follows a receptor-mediated endocytosis (RME) pathway that was originally described by Brown and Goldstein in 1986 (14). When the LDLR protein function is diminished as a result of defects in the LDLR gene, the mechanism of uptake is inhibited, so that cholesterol is increased in plasma, and atherosclerosis will develop eventually (15).

Five classes of LDLR gene mutations have been identified: cLass 1 mutations where the LDLR protein is not synthesized, resulting in a receptor-negative mutation (14); class 2 mutations where the synthesized LDLRs are not transported to the Golgi apparatus; class 3 mutations where the LDLRs do not bind to the LDL particles; class 4 mutations where the LDLRs are not internalized from the surface of the cells; and finally, class 5 mutations where the LDL particles are internalized but are not released into the endosome. Mutations of classes 2-5 are classified as defective receptor mutations. The majority of mutations that have been identified to date are in class 2 and 3 mutations (15). More than 1100 different mutations have been identified in the LDLR gene (16).

The APOB-100 protein is responsible for the removal of LDL particles from the circulation through its role as a ligand for the LDLR (17). Studies that were done in the preceding decade demonstrated that similar clinical presentation of $\mathrm{FH}$ patients might be due to mutations in APOB-100 gene (18). APOB-100 gene spans $43 \mathrm{~kb}$ and is located on the chromosome 2p23-24. It encodes a 4,536-amino acid protein and is the only protein component of LDL particles acting as a ligand to the LDLR. A defect in the APOB-100 gene may disrupt the binding of LDL to its receptor, resulting in an improper clearance of the LDL from the plasma and subsequent hypercholesterolaemia (19). A clinical phenotype that is caused by a mutation in APOB100 gene is the "familial defective apolipoprotein B-100" mutation defect or "FDB". Mutations that can cause FDB are located at the LDL binding domain of the APOB -100 gene, at exons 26 and $29(20,21)$.

Several types of APOB-100 gene mutations have been reported, and the most characterised mutations reported are p.Arg3500Glu (22), p.Arg3500Tryp (23) and p.Arg3531Cys (24).

Autosomal dominant hypercholesterolaemia (ADH) can also be a result of a mutation in the PCSK9 gene (25) that spans around $25 \mathrm{~kb}$, and resides on the chromosome $1 \mathrm{p} 32$ (26). The PCSK9 protein consists of 694 amino acids and is a part of the proprotein convertase subtilase family. It is secreted by hepatocytes and it produces its action by the down-regulation and the degradation of the LDLRs, instead of their recycling to the cell surface. PCSK9 gene defects that cause hypercholesterolaemia are probably gain-of-function mutations, as over-expression of the PCSK9 protein in the liver of mice produces hypercholesterolaemia by reducing the number of functional LDLRs (27). The loss-of-function mutations have an opposite effect with a reduction in both LDL-C and coronary heart disease (CHD) risks (28).

Apolipoprotein E (APOE) has an essential role in the metabolism of the highly atherogenic APOB containing lipoproteins (LDL) (29). Coronary heart disease risk are reported to be associated with the APOE gene variations (30). It was estimated that the APOE polymorphisms contribute to $2-16 \%$ of the changes in the LDL-C levels. The E4 allele and E2 allele are associated with a higher and a lower plasma LDL-C levels, respectively (31).

Hypercholesterolaemia can also be inherited in an autosomal recessive manner by a mutation in the low-density lipoprotein receptor adaptor protein (LDLRAP1) gene, known as the autosomal recessive hypercholesterolaemia gene (ARH). The gene is located at the chromosome $1 \mathrm{p} 36.11$, spanning about $47 \mathrm{~kb}$ and coding for a 308 amino acid putative adaptor protein that is used in the LDLR endocytosis process (32). This protein cooperates with the cytoplasmic tail of the LDLR (33). It acts during RME through the internalisation process by linking the LDLRs to their endocytic element of the coated pits (34). An ARH gene mutation can cause a defect in the adaptor protein function and restrict the uptake of LDL from the cell surface by LDLRs (33). Patients with ARH have a plasma LDL-C level that is intermediate between the $\mathrm{FH}$ heterozygous and homozygous patients (34). 


\section{Importance of the diagnosis of familial hypercholesterolaemia}

It was reported that untreated $\mathrm{FH}$ patients had a 3-4 times higher risk for coronary heart disease (CHD) compared to unaffected subjects, with an occurrence of CHD at a decade earlier (35). It is for this reason that it is very important to diagnose $\mathrm{FH}$ not only for a better prognosis but also for the benefit of other family members. In the past, patients with $\mathrm{FH}$ typically presented with premature $\mathrm{CHD}$, but presently for patients who may have a higher level of education, a greater awareness and the easier availability of biochemical investigations, an earlier diagnosis should be possible. Those with heterozygous phenotypes have tendon manifestations alone while those with a homozygous phenotype may have both tendon and cutaneous manifestations. In patients with a heterozygous phenotype, early signs of atherosclerosis may be identified during the second decade of life whereas, in patients with a homozygous phenotype, they can be clearly seen in the first decade of life.

Three groups have been established with the diagnostic tools for FH: the United States Med Ped Program (36), the Simon Broome Register Group in the United Kingdom (37) and the Dutch Lipid Clinic Network (38). Genetic counselling can improve the outcome for $\mathrm{FH}$ patients. Counsellors, together with the correct genetic testing results, are essential for proper patient support and the clarification and direction for family screening (39). Despite an extensive screening program that was established over twenty years ago, a substantial proportion of patients with $\mathrm{FH}$ are still undiagnosed and remain undertreated. $\mathrm{A}$ genetically based family cascade screening was performed in the Netherlands and over 64,000 persons were tested, of whom $40.3 \%$ were found to carry $\mathrm{FH}$ causing mutation. It is a challenge to arrange a country-wide program for the diagnosis and screening of $\mathrm{FH}(40)$, and genetic cascade testing approach has proved to be cost-effective (41).

The International FH Foundation has recently presented guidelines for $\mathrm{FH}$ (42) in Asia, and Japanese guidelines have been recently published (43). Most of the data of $\mathrm{FH}$ are from western investigators with few studies from Asia $(44,45)$. One such study is a review was published by Alex Livy and Say Hean Lye on genetic research among Asian familial hypercholestralaemic patients (46). Although $\mathrm{FH}$ is being identified and clearly diagnosed clinically in Malaysia, only a few genetic studies have been reported from the population. Here, we provide an overview of the molecular studies on SNPs and gene mutations of $\mathrm{FH}$ among Malaysians.

\section{Studies in Malaysian familial hypercholestrolaemic subjects}

An extensive search was done for data on $\mathrm{FH}$ among Malaysians based on online libraries: PUBMED, Scopus, Google Scholar, and Medline from 1990-2015. 11 articles were identified and reviewed.
In 1997, Khoo KL et al. screened for APOB -100 gene mutations in 163 clinically hyperlipidaemic patients with a high cholesterol level in Kuala Lumpur. Mutations in the APOB-100 gene were determined by using polymerase chain reaction (PCR) and Denaturating Gradient Gel Electrophoresis (DGGE), followed by a DNA sequencing to confirm the presence of an APOB -100 gene defect. Only three point mutations were identified among four patients. Two women, a Chinese and a Malay, had the same mutation, p.Arg3500 Trp. Two silent mutations, p.Ala3527 Ala and p.Leu3517 Leu, were identified. They concluded that the common p.Arg3500 Trp mutation could be identified among Asians supported by haplotype analysis of the APOB-100 gene. This gene might, therefore, have Asian ancestry as it appeared among Asians. The team recommended that further studies for the screening of APOB-100 gene mutations among a larger Asian population with ADH were needed (47).

In the year 2000, Khoo KL et al hypothesized that in Asia, heterozygous FH subjects had less severe clinical phenotype than subjects from other parts of the world. With the role of LDLR and APOB-100 gene mutations yet to be ascertained, Khoo KL et al. screened for both LDLR and APOB-100 genes among eighty-six Malaysian FH patients, each patient with a total cholesterol level $>7.0 \mathrm{mmol} / \mathrm{L}$, and with an ADH pattern of inheritance. PCR - DGGE analyses of the promoter and the 18 exons of the LDLR gene were done. Mutagenic PCR and restriction digestion with the endonuclease restriction enzyme, Mspl, followed by electrophoresis was carried out for exon 26 of the APOB-100 gene. The sequence variants were confirmed by DNA sequencing. Eighteen mutations of the LDLR gene were reported with a frequency of $26 \%$. No mutation was detected in the APOB-100 gene. More than $70 \%$ of $\mathrm{FH}$ patients had neither LDLR nor APOB-100 genes mutation, suggesting the existence of a third gene with a milder form of FH among Southeast Asians. The team recommended genetic screening for families with a clinical diagnosis of $\mathrm{FH}$ without an identified LDLR gene defect, for the detection of other genes causing a similar but a milder clinical presentation of $\mathrm{FH}(48)$.

Khoo $\mathrm{KL}$ and his team further reported the location of the LDLR gene defects and showed that $4 \%$ of the familial hypercholestrolaemic patients studied, had a mutation in the promoter region, whereas $35 \%$ carried the mutation in the ligand binding domain, of which $9 \%$ of the patients had the mutation in exon 4 (49). The LDLR gene mutation database has summarized by the British Heart Foundation with about $40.7 \%$ of the LDLR gene variants within the ligand binding domain in exon 2-4 whilst exon 4 carried the highest frequency (16). Such a high frequency was could either be explained by the big size of this exon (1), or to a bias in the selection of the patients, where subjects with a functional mutation in exon 4 presented with a more severe clinical phenotype (50). Exon 4 encodes for the 5 th repeat of the LDLR protein, and this repeat is important for both the low-density lipids (LDL) binding through APOB and the very low-density lipids (VLDL) through the apoprotein-E 
(APOE) (13), and might explain the severe phenotype presentation of the patient with the exon 4 genetic defect.

In 2006, Azian et al (51) investigated $72 \mathrm{FH}$ subjects. Mutational screening analysis was performed by DGGE for all exons of the LDLR except for the promoter region, exon 4-3' and exon 18 that were screened by direct sequencing, due to difficulties in optimising DGGE, and for the APOB-100 genes. Positive mutations were confirmed by DNA sequencing. Four mutations were discovered in the LDLR gene among $19.4 \%$ of patients. No mutation in the APOB-100 gene could be reported. This was the first report for p.Cys234Ser mutation in exon 5. The p.Asp69Asn mutation in exon 3 had been reported among Malaysians, while p.Arg385Trp mutation in the exon 9 and p.Arg716Gly mutation of the exon 15 had not been reported locally. Additionally, four SNPs were identified: p.Arg450Arg, p.Asn510Asn, p.Asn570Asn, and p.Val632Val. As the LDLR mutation was only reported among $19 \%$ of the study cohort, about $80 \%$ of the subjects had no mutation, again suggesting that other genes might contribute to the $\mathrm{FH}$ phenotype. The DGGE method had a low sensitivity rate of $80 \%(48)$ and the use of a faster and more sensitive mutational screening method together with the search for additional genes that can cause a clinical disorder equivalent to $\mathrm{FH}$ was recommended (51).

Al-Khateeb et al in 2011 (52) studied further a group of 154 unrelated familial hypercholaestrolaemic patients from Hospital University Sains Malaysia (HUSM). The promoter region and exons 2-15of the LDLR gene were screened using denaturing high-performance liquid chromatography (DHPLC) to detect point mutations, small deletions and duplications. Multiplex ligation-dependent probe amplification (MLPA) was performed to detect large rearrangements. This study reported on 29 genes sequence variants with an overall mutation detection rate of $42.2 \%$ which was almost double that reported $(51,48)$. Eight mutations and 21 variants were described, with eight novel gene sequence variants in the $\mathrm{FH}$ patients, but not in the controls: p.Asp100Asp, p.Asp139His, p.Arg471Gly, c. $1705+117 T>G$, c. $1186+41 T>A, 1705+112 C>G$, Dup exon 12 and $p . T r p 666$ Profs $X 45$. The novel large rearrangement mutation was reported at a frequency of $1.3 \%$. It was the first report of duplication in the LDLR gene among Malaysian. A higher frequency of $8 \%$ in the large LDLR rearrangement, had been reported in Taiwanese $\mathrm{FH}$ patients (53). The use of DHPLC had a higher sensitivity, and together with the applications of MLPA in the detection of LDLR mutation, contributed to the greater percentage of positive molecular diagnosis of $\mathrm{FH}$.

A study showed that patients with a large rearrangement mutation in the LDLR gene had a higher LDL-C levels and that statin treatment was less able to lower LDL-C level. It was identified that the rearrangement in the LDLR gene would result in a "null-receptor" or a truncated protein that lacked essential domains for proper LDLR function (53). Eight mutations were reported to be pathogenic by an insilico analysis. However, family and protein study would be needed to confirm the pathogenicity of those mutations.
The University Malaya Medical Centre (UMMC) reported on 144 clinically diagnosed $\mathrm{FH}$ patients. Screening for the 18 exons of the LDLR gene was completed by PCR and direct DNA sequencing. A novel missense mutation, p.Cys711Tyr, in exon 14 of the LDLR gene was reported for the first time in Asia. This mutation was identified as a probable damaging mutation based on PolyPhen prediction (54). The epidermal growth factor (EGF) -precursor homology domain of exons 7-14 is essential for the receptor recycling process and for lipoprotein release in low $\mathrm{pH}$ conditions (55). Mutation in this domain would disrupt the uptake of cholesterol-carrying particles into the cells, resulting in hypercholesterolaemia. An extensive determination of the pathogenicity for each reported mutation would help in the confirmation of the disease-causing mutation in the index cases. Screening of the family members would contribute to an earlier diagnosis and treatment, improving the outcome of $\mathrm{FH}$ patients.

A number of genetic markers, including SNPs and/or mutations in LDLR, APOB- 100 and PCSK9 genes have been reported worldwide. Those data are important for the purpose of a universal screening and management of ADH. However, such data from Malaysians are very few. This stimulated research to identify ADH-causing mutations and associated SNPs among the multiethnic Malaysian population (56), in LDLR, APOB-100 and PCSK9 genes in $140 \mathrm{ADH}$ patients, diagnosed using the Dutch Lipid Criteria and 111 controls. Genotyping assay for 310 previously recognised point mutations and/ or SNPs was performed. Selection of SNPs was initiated from the online databases for the three genes through the British Heart Foundation (BHF) (http://www.ucl.ac.uk/ldlr/), dbSNP (http://www. ncbi.nlm.nih.gov/projects/SNP/) and the SNPedia (www. snpedia.com). Microarray and genotyping assays were performed with the Illumina Golden Gate Genotyping (GGGT). The confirmation of the allele detected by the microarray was performed by sequencing of randomly selected samples. The team reported on 137 mono-allelic markers, 44.1\%, and 173 polymorphic markers, 55.8\%, among the autosomal dominant hyperchlesterolaemic studied population. Failure of the study to report on a minor allele among the subjects indicated that these genetic markers could not be used as biomarkers for $\mathrm{FH}$ among Malaysians ADH patients (56).

By comparing their findings to the public database (http:// www.ncbi.nlm.nih.gov/projects/ SNP), only 23 markers showed significant differences in the allele frequency among Malaysians, European Whites, Chinese, Yoruba and Indians. There were five SNPs related to ADH in Malaysians that were non-conservative amino-acid changes in the public database. They concluded that the variants that contributed to ADH susceptibility among other populations might not be of concern among Malaysians. Genetic markers must be a population specific and further genetic studies to characterise the full range of alterations among Malaysians are indicated, including the association of the reported SNPs and /or mutations with the phenotype of $A D H$, and a segregation or haplotype study for those variants (56). 
Hean Lye et al further hypothesised that SNPs could exert their effects separately and that multiple SNPs could act synergistically to alter the susceptibility to the disease. They investigated the association of previously reported genetic variants that were involved in regulation of lipid among Malaysian FH patients. The samples were collected from 141 patients with clinical diagnosis of $\mathrm{FH}$ and in 111 unrelated controls at the UMMC. Genetic variations were derived from three publically databases: British Heart Foundation (BHF), dbSNP, and SNPedia. Polymorphisms previously implicated in $\mathrm{FH}$ were sent to Illumina for designing the probes. Only 1536 variations were designed to the Illumina criteria. Then high throughput microarray genotyping analysis was performed. Fourteen SNPs were found to be significantly associated with $\mathrm{FH}$; eleven were associated with an increasing $\mathrm{FH}$ risk, of which only one SNP was reported in LDLR gene, seven in the APOB -100 gene, and three in the PCSK9 gene. This report is the first to highlight the PCSK9 gene variants among Malaysian FH patients. Three SNPs were associated with decreasing FH risk.

The authors reasoned that the lack of an association with ADH could be explained by the mono-allelic nature (56). The lack of an association could be also be explained by the non-significant difference between the cases and the controls that were recruited in the study. Many of the published SNPs could be non-causative polymorphisms among Malaysian ADH patients and further validation in a larger cohort of Asian descent was recommended together with family and in vitro studies to confirm the pathogenicity of the variants (57).

There are few investigations in the Malaysian $\mathrm{FH}$ population to determine a gene variant in the APOB -100 gene. AL Khateeb et al studied 164 patients attending HUSM. The subjects were selected according to the Simon Broome Register diagnostic criteria for $\mathrm{FH}$ (37). All patients were screened for APOB -100 gene variants. DHPLC and DNA sequencing were used to identify the mutations in exons 26 and 29 of this gene. The team was able to identify 10 variants. The five novel mutations discovered by this study were p.GIn2485Arg, p.Thr3526Ala, p.Glu3666Lys, p.Tyr4343CysfsX221, and p.Arg4297His. The focus for future study would be on both the APOB-100 and the LDLR genes as causes for ADH rather than on the LDLR gene alone (58).

Patients with LDLR gene variants have a different phenotype from those patients with APOB-100 gene variants, and the type of mutation is a well-known contributing factor to the clinical presentation of $\mathrm{FH}$ patients. In 2013. Al-Khateeb et al presented the association of different gene variants in LDLR and APOB-100 genes with the clinical phenotype among Malaysian FH subjects. A group of 164 patients with the clinical diagnosis of $\mathrm{FH}$ were recruited and analysed from HUSM. This study reported that carriers of APOB100 gene mutation have a significantly higher frequency of CVD, $83.3 \%$ vs. $64.9 \%$, a higher LDL-C level, $5.2 \mathrm{mmol} / \mathrm{l}$ vs. $4.7 \mathrm{mmol} / \mathrm{l}$, and a higher TC:HDL-C ratio, $7.2 \mathrm{mmol} / \mathrm{I}$ vs
$6.1 \mathrm{mmol} / \mathrm{l}$, than the non-carrier patients with $\mathrm{p}$ of 0.045 , $p$ of 0.03 and $p$ of 0.02 , respectively (59). Mutations in this gene may result in a defective APOB protein function, so that the uptake of LDL-C from the circulation by LDLR is impaired, resulting in hyperlipidaemia, high LDL-C and the development of CVD. For patients with the LDLR gene defects, those with frame shift mutation showed the worst clinical presentation in terms of LDL-C level and cardiovascular disease frequency. They concluded that there was an association between mutations in LDLR and APOB -100 genes with a history of CVD, a younger age of clinical presentation, a family history of hyperlipidemia, TX and a higher LDL-C level (59).

Only one Malaysian case report could be identified (60). A twenty-two-year-old Malay woman presented with soft tissue injuries after a car accident. A positive family history of PCVD was elucidated, and a clinical examination revealed the presence of xanthelasma. Biochemical investigations demonstrated a very high total cholesterol (TC) of 15.3 $\mathrm{mmol} / \mathrm{L}$, and low-density lipid (LDL) -C of $3.9 \mathrm{mmol} / \mathrm{L}$. A screening of the LDLR and the APOB-100 genes using DHPLC revealed a homozygous mutation of p.Cys $255 \mathrm{Ser}$ at the exon 5 of the LDLR gene. This mutation had been previously described in the affected Malaysian population $(51,52)$.

This case report highlights the importance of a genetic screening in the clinically diagnosed patient in order to ensure an early confirmation and early treatment, to lessen the risk of the development of CHD.

Table 1, 2 and 3 summarised the genetic findings in the LDLR, APOB-100 and PCSK9 genes, respectively among Malaysian FH patients.

\section{Discussion}

Familial hypercholesterolaemia is a common monogenic disorder of lipid metabolism that is associated with an increasing the risk for premature CVDs. It is important to ensure the correct diagnosis so that an early and appropriate therapy can be assured. Diagnosis is based on the clinical presentation of the patient with high LDL-C levels and is confirmed by genetic testing. Most of the information about $\mathrm{FH}$ is based on the data from western countries, with few reports from in Asia including Malaysia. A variety of LDLR gene mutations have been reported among the Malaysians including silent, missense, splice site mutations and even large rearrangements; this may reflect the genetic heterogenicity of the Malaysian familial hypercholesterolemic population.

The spectrum of mutations among Malaysian FH patients is unlike that of other countries. The in-frame deletion of a single amino acid and the large deletion detected among European familial hypercholesterolaemic subjects (61), could not be identified among the Malaysians. Europe and South East Asia have received migrants from all parts of the world and the spectrum of LDLR gene mutations will reflect the greater diversity in the genetic background of 
Table 1: Summary of the LDLR gene variants

\begin{tabular}{|c|c|c|c|c|c|c|}
\hline No & Sample size & Method & Region & Mutation /variant & $\%$ & Reference \\
\hline $1-$ & 86 & $\begin{array}{l}\text { DGGE, mutagenic PCR } \\
\text { and restriction } \\
\text { digestion }\end{array}$ & $\begin{array}{l}\text { Promoter } \\
\text { Exon } 2 \\
\text { Exon } 3 \\
\text { Intron } 3 \\
\text { Exon } 4 \\
\text { Exon } 5 \\
\text { Exon } 6 \\
\text { Exon } 7 \\
\text { Exon } 8 \\
\text { Exon } 9 \\
\text { Exon } 10 \\
\text { Exon } 14\end{array}$ & $\begin{array}{l}\text {-152 G<T } \\
\text { 77del GA } \\
\text { p.Asp69Asn } \\
\text { c. 313+1 G<A } \\
\text { p.Arg94His } \\
\text { p.Arg232Trp } \\
\text { p.Glu256 Lys } \\
\text { p.Cys308Tyr } \\
\text { p.Gln357ter } \\
\text { p.Lys372Asn } \\
\text { p.Leu393Arg } \\
\text { p.lle402Thr } \\
\text { p.Asn407Lys } \\
\text { p.Gly457Arg } \\
\text { p.Asp471Asn } \\
\text { 2108ins7bp } \\
\text { p.Ala663Thr } \\
\text { p.Cys675Thy }\end{array}$ & $\begin{array}{l}1.2 \\
1.2 \\
1.2 \\
1.2 \\
2.4 \\
2.4 \\
1.7 \\
2.4 \\
1.2 \\
1.2 \\
2.4 \\
1.2 \\
1.2 \\
1.2 \\
1.2 \\
1.2 \\
1.2 \\
1.2\end{array}$ & Khoo et al.2000 \\
\hline $2-$ & 72 & DGGE, mutagenic PCR & $\begin{array}{l}\text { Exon } 3 \\
\text { Exon } 5 \\
\text { Exon } 9 \\
\text { Exon } 15 \\
\text { Exon } 10 \\
\text { Exon } 11 \\
\text { Exon } 12 \\
\text { Exon } 13\end{array}$ & $\begin{array}{l}\text { p.Asp69Asn } \\
\text { p.Cys255Ser } \\
\text { p.Arg716Gly } \\
\text { p.Arg385Trp } \\
\text { p.Arg450Arg } \\
\text { p.Asn510Asn } \\
\text { p.Asn570Asn } \\
\text { p.Val632Val }\end{array}$ & $\begin{array}{l}1.4 \\
12.5 \\
2.8 \\
1.4 \\
\text { Not reported } \\
\text { Not reported } \\
\text { Not reported } \\
\text { Not reported }\end{array}$ & Azian et al. 2006 \\
\hline $3-$ & 154 & $\begin{array}{l}\text { DHPLC and } \\
\text { Sequencing }\end{array}$ & $\begin{array}{l}\text { Exon } 2 \\
\text { Intron } 2 \\
\text { Exon } 3 \\
\text { Exon } 4 \\
\text { Exon } 5 \\
\text { Exon } 6 \\
\text { Intron } 6 \\
\text { Intron } 7 \\
\text { Intron } 8 \\
\text { Exon 9 } \\
\text { Intron } 9 \\
\text { Exon } 10 \\
\text { Exon } 11 \\
\text { Intron } 11 \\
\\
\text { Exon } 15\end{array}$ & $\begin{array}{l}\text { p.Cys27Cys } \\
\text { c.190+58C }>\mathrm{T} \\
\text { c.190+56G }>\mathrm{A} \\
\text { c.190+4A }>\mathrm{T} \\
\text { p.Asp100Asp } \\
\text { p.Glu101Lys } \\
\text { p.Asp139His } \\
\text { p.Glu201Lys } \\
\text { p.Cys255Ser } \\
\text { p.Asp304Asn } \\
\text { c.940+36G }>\mathrm{A} \\
\text { c.1060+7 T>C } \\
\text { c.1060+10 G>C } \\
\text { c.1186+41T }>A \\
\text { p.Ile398 Ile } \\
\text { c.1359-30C }>\mathrm{T} \\
\text { p.Arg471Gly } \\
\text { p.Pro539Pro } \\
\text { c.1705+56C }>\mathrm{T} \\
\text { c.1705+117T }>\mathrm{G} \\
\text { c.1706-69G }>\mathrm{T} \\
\text { c.1705+112C }>\mathrm{G} \\
\text { c.1706-55A }>\mathrm{C} \\
\text { p.Asn591Asn } \\
\text { Dup exon } 12 \\
\text { p.Val653Val } \\
\text { p.Asp700Glu } \\
\text { p.Trp666ProfsX45 } \\
\text { p.Arg744Arg }\end{array}$ & $\begin{array}{l}0.6 \\
4.5 \\
1.9 \\
0.6 \\
0.6 \\
7.1 \\
0.6 \\
5.8 \\
6.5 \\
4.5 \\
1.8 \\
11.7 \\
3.2 \\
0.6 \\
3.2 \\
1.3 \\
11 \\
3.9 \\
7.8 \\
1.3 \\
0.6 \\
0.6 \\
3.9 \\
4.5 \\
1.3 \\
0.6 \\
3.2 \\
2.6 \\
4.3\end{array}$ & Alyaa et al.2013 \\
\hline
\end{tabular}




\begin{tabular}{|l|l|l|l|l|l|l|}
\hline No & Sample size & Method & Region & Mutation /variant & $\%$ & Reference \\
\hline $4-$ & 141 & Microarray & $\begin{array}{l}\text { Intron 15 } \\
\text { Intron 6 }\end{array}$ & $\begin{array}{l}\text { rs10422244 [T/C] } \\
\text { rs61318752 [G/T] }\end{array}$ & Not reported & Alex et al.2012 \\
\hline $5-$ & 141 & Microarray & $\begin{array}{l}\text { Not } \\
\text { reported }\end{array}$ & rs2569556 [G/A] & Not reported & Lye et al.2013 \\
\hline 6- & 144 & Sequencing & Exon 14 & p.Cys711Tyr & 1.4 & Chahil et al.2012 \\
\hline $7-$ & Case report & $\begin{array}{l}\text { DHPLC and } \\
\text { Sequencing }\end{array}$ & Exon 5 & p.Cys255Ser & Not reported & Alicezahetal.2014 \\
\hline
\end{tabular}

Table 2: Summary of the $A P O B-100$ gene variants

\begin{tabular}{|c|c|c|c|c|c|c|}
\hline No & Sample & Method & Region & Mutation/variant & $\%$ & Reference \\
\hline 1- & 163 & DGGE & Exon 26 & $\begin{array}{l}\text { p.Leu3517Leu } \\
\text { p.Arg3500Trp } \\
\text { p.Ala3527Ala }\end{array}$ & $\begin{array}{l}0.6 \\
1.2 \\
0.6\end{array}$ & $\begin{array}{l}\text { Choong et } \\
\text { al. } 1997\end{array}$ \\
\hline $2-$ & 141 & Microarray & $\begin{array}{l}\text { Exon } 26 \\
\text { Exon } 29\end{array}$ & $\begin{array}{l}\text { p.lle2716lle } \\
\text { p.Leu2680GIn } \\
\text { p.His3182Asn } \\
\text { p.Val4128Met }\end{array}$ & $\begin{array}{l}\text { Not reported } \\
\text { Not reported }\end{array}$ & $\begin{array}{l}\text { Alex etal. } \\
2012\end{array}$ \\
\hline $3-$ & 141 & Microarray & $\begin{array}{l}4291 \\
1722 \\
11742 \\
28640 \\
5287 \\
22106 \\
24881 \\
7009\end{array}$ & $\begin{array}{l}\text { rs13306187[G/A] } \\
\text { rs13306194[G/A] } \\
\text { rs12714238[G/A] } \\
\text { rs12720772[G/A] } \\
\text { rs12720762[G/C] } \\
\text { rs41291161[T/A] } \\
\text { rs57825321[A/T] } \\
\text { rs12714254[T/G] }\end{array}$ & Not reported & $\begin{array}{l}\text { Lye et al. } \\
2013\end{array}$ \\
\hline 4- & 164 & DHPLC and Sequencing & $\begin{array}{l}\text { Exon } 26 \\
\text { Exon } 29\end{array}$ & $\begin{array}{l}\text { p.Thr2515Thr } \\
\text { p.GIn2485Arg } \\
\text { p.Thr3526Ala } \\
\text { p.Thr3567Met } \\
\text { p.Glu3666Lys } \\
\text { Thr3567Thr } \\
\text { p.Arg4297His } \\
\text { p.Ser4338Asn } \\
\text { p.Arg4270Thr } \\
\text { P.Tyr4343CysfsX2 }\end{array}$ & $\begin{array}{l}49.4 \\
7.3 \\
3.7 \\
1.8 \\
0.6 \\
2.4 \\
1.8 \\
2.4 \\
19.5 \\
2.7\end{array}$ & $\begin{array}{l}\text { Alyaa et al. } \\
2013\end{array}$ \\
\hline
\end{tabular}

Table 3: Summary of the PCSK9 gene variants

\begin{tabular}{|c|c|c|c|c|c|c|}
\hline No & Sample size & Method & Region & Mutation / variant & $\%$ & Reference \\
\hline 1- & 141 & Microarray & Intron 5 & $\begin{array}{l}\text { rs28385711 [C/G] } \\
\text { rs17111555 [A/G] } \\
\text { rs17111557 [T/C] }\end{array}$ & Not reported & Alex et al. 2012 \\
\hline $2-$ & 141 & Microarray & $\begin{array}{l}15015 \\
24382 \\
24924\end{array}$ & $\begin{array}{l}\text { rs12084215[C/A] } \\
\text { rs565436[A/G] } \\
\text { rs28362269[G/A] }\end{array}$ & Not reported & Lye et al. 2013 \\
\hline
\end{tabular}


both the migrant and native population. For the LDLR gene, p.Cys255Ser mutation has been reported in more than one Malaysian study $(51,52,60)$, with a higher frequency of $12.5 \%$ by Azian et al followed by $6.5 \%$ by Alyaa et al, and led to the conclusion that this mutation is common among the affected Malaysians. Other point mutations are common among the Christian Lebanese (62) and specific LDLR gene mutations in French Canadian subpopulation (63). From previous studies, the exon 14 and exon 9 were the hot spots as they carried the highest number of gene variants, the 6 and the 5 variant, respectively $(48,52)$ yet the $\mathrm{FH}$ public database from http://www.ucl.ac.uk/fh. showed that exon 4 carried the highest variant number, and was not applicable to every sub-population group in the UK as Taylor et al. reported the highest variant number were in both exon 10 and 13 (64).

Among on the Malaysians, the mutation detection rate was variable ranging from $42.2 \%$ by Alyaa et al to $19 \%$ by Azian et al and to $26 \%$ by Khoo et al. The higher detection rate by Alyaa et al might be attributed to the use of DHPLC and sequencing plus MLPA that could detect the large rearrangement of the LDLR gene in comparison to the DGGE that was used by the other groups. A study in the UK using DHPLC/sequencing reported a mutation detection rate of about $51 \%$ (64).

An important challenge of the LDLR genetic testing is gene coverage. The promoter region cannot be sequenced by many clinical laboratories because the interpretation of gene variants in this area is difficult. Only a few variants have been identified within the promoter and the $5^{\prime}$ UTR gene region among Malaysians $(49,65)$. To confirm the pathogenicity of mutations is not easy as the confirmation of the pathogenicity requires functional studies of segregation analysis and protein study.

Apart from Chong et al, who was able to confirm the p.Arg3500Trp mutation, the previously reported common global mutations of the APOB -100 gene could not be confirmed among Malaysian FDB. APOB-100 gene mutation was detected at a frequency of $12 \%$ among our population (58), this frequency is high in comparison to another study that also used DHPLC as a method of detection of $2.3 \%$ (66). This can be explained by the wider region (exons 26 and 29) in comparison to only exon 26 that was screened by the other study.

The data about the PCSK9 is very limited among Malaysians with only two studies and a few variants reported. PCSK9 mutations are relatively common in Japan with a frequency of $5.9 \%$, and cause a milder phenotype compared with the LDLR mutations (67).

The phenotypic expression of $\mathrm{FH}$ is dependent on the functional consequence of the mutation, the interactions with other genes that regulate the circulating lipid levels, and the effects of the environment (68). Despite the monogenic nature of the disorder, $\mathrm{FH}$ shows a large variability in phenotypic expression in terms of the lipid profile, the frequency of xanthomas, the age of onset and the severity of CVD (69).
Among the studies that have been carried out, those with LDLR gene mutations have a higher prevalence of CVD and a higher LDL-C in comparison to those without apparent genetic mutations $(48,52)$ and the LDLR gene mutation has been identified as a predictor for CVD among Malaysian FH patients (59). These two findings are in agreement with an observation among Taiwanese $\mathrm{FH}$ cases (53). The worst phenotype was reported among those with a frameshift mutation, in terms of CVD frequency and lipid profile parameters compared to those with the large rearrangement mutations, although both mutations are classified as a null mutation type (70). This finding is opposite to another study in which FH patients with large rearrangements are associated with a more severe biochemical phenotype compared to other mutation types (71). The latter result may be explained by the small sample size of the large rearrangement group. As a general rule, null mutations and LDLR-negative familial hypercholesterolaemic patients are associated with higher levels of LDL-C, more imaging markers of cardiovascular disease (CVD), and more adverse CVD outcomes (72). However, this clinical presentation was not seen clearly among the Malaysians.

\section{Conclusion}

The variety of mutations that have been reported in the LDLR gene suggests that the genetic background of Malaysian FH is diverse. Many FH patients do not express any sequence variant, suggesting that $\mathrm{FH}$ in Malaysia may be caused by mutations in genes other than LDLR or APOB-100 gene. Many of the reports were not able to identify the APOB -100 gene variant as a causative defect. Hypercholesterolaemia is a silent disease and the underlying aetiology of $\mathrm{FH}$ is still not well defined.

\section{Recommendations}

There is a strong need to engage in systematic sequencing studies of index patients to discover novel mutations and simultaneously to establish a cascade screening for the relatives of index cases so that the affected people can be traced early and managed properly. A population-based study is recommended to look for other gene defects that may predispose to FH-like phenotypes. Research on mutations in the genes controlling lipid metabolism is needed. In-vivo study to look for the pathogenicity of the gene variants in man is crucial. The research that was done by individual groups is promising. Appropriate genetic tests are needed to be adopted by the government at a national level for the establishment of a screening program to ensure an earlier diagnosis and management for a better outcome for the patient and family.

\section{References}

1. Austin MA, Hutter CM, Zimmern RL, Humphries SE. Genetic causes of monogenic heterozygous familial hypercholesterolemia: a huge prevalence review. Am. J. Epidemiol. 2004; 160(5):407-20. 
2. Hovingh GK, Davidson MH, Kastelein JJ, O'Connor AM. Diagnosis and treatment of familial hypercholesterolaemia. Eur Heart J. 2013; 34(13):96271.

3. Marks D, Thorogood M, Neil HAW, Humphries $\mathrm{SE}$. A review on the diagnosis, natural history, and treatment of familial hypercholesterolaemia. Atherosclerosis. 2003; 168(1):1-14.

4. Sjouke B, Kusters DM, Kindt I, Besseling J, Defesche JC, Sijbrands EJ, et al. Homozygous autosomal dominant hypercholesterolaemia in the Netherlands: prevalence, genotype-phenotype relationship, and clinical outcome. Eur Heart J 2014:ehu058.

5. Ademi Z, Watts GF, Pang J, Sijbrands EJ, van Bockxmeer FM, O'Leary $\mathrm{P}$, et al. Cascade screening based on genetic testing is cost-effective: evidence for the implementation of models of care for familial hypercholesterolaemia. J Clin Lipidol 2014; 8:390-400.

6. Marais AD. Familial hypercholesterolaemia. Clin Biochem Rev. 2004; 25(1):49-68.

7. Benn M, Watts GF, Tybjaerg-Hansen A, Nordestgaard BG. Familial hypercholesterolemia in the Danish general population: prevalence, coronary artery disease, and cholesterol-lowering medication. J Clin Endocrinol Metab. 2012; 97(11):3956-64.

8. Nordestgaard BG, Chapman MJ, Humphries SE, Ginsberg HN, Masana L, Descamps OS, et al. Familial hypercholesterolaemia is underdiagnosed and undertreated in the general population: guidance for clinicians to prevent coronary heart disease. Eur Heart J. 2013; 34(45):3478-90.

9. Shi Z, Yuan B, Zhao D, Taylor AW, Lin J, Watts GF. Familial hypercholesterolemia in China: prevalence and evidence of underdetection and undertreatment in a community population. Int J Cardiol. 2014; 174(3):834.

10. Goldstein JL, Brown MS. Binding and Degradation of Low Density Lipoproteins by Cultured Human Fibroblasts Comparison Of Cells From A Normal Subject And From A Patient With Homozygous Familial Hypercholesterolemia. J. Biol. Chem. 1974; 249(16):5153-62.

11. Lindgren V, Luskey $\mathrm{KL}$, Russell DW, Francke U. Human genes involved in cholesterol metabolism: chromosomal mapping of the loci for the low density lipoprotein receptor and 3-hydroxy-3methylglutaryl-coenzyme A reductase with cDNA probes. Proceedings of the National Academy of Sciences. 1985; 82(24):8567-71.

12. Sudhof TC, Russell DW, Goldstein JL, Brown MS, Sanchez-Pescador R, Bell Gl. Cassette of eight exons shared by genes for LDL receptor and EGF precursor. Science. 1985; 228(4701):893-5.

13. Hobbs HH, Brown MS, Goldstein JL. Molecular genetics of the LDL receptor gene in familial hypercholesterolemia. Hum. Mutat. 1992; 1(6):44566.
14. Brown MS \& Goldstein JL. A receptor-mediated pathway for cholesterol homeostasis. Science. 1986; 232(4746):34-47.

15. Brown MS, Goldstein JL. How LDL receptors influence cholesterol and atherosclerosis. Sci Am. 1984; 251(5):58-66.

16. University College London Low Density Lipoprotein Familial Hypercholesterolaemia Database. http:// www.ucl.ac.uk/fh.

17. Rader DJ, Cohen J, Hobbs HH. Monogenic hypercholesterolemia: new insights in pathogenesis and treatment. J Clin Invest. 2003; 111(12):1795-803.

18. Innerarity TL, Weisgraber KH, Arnold KS, Mahley RW, Krauss RM, Vega GL, et al. Familial defective apolipoprotein B-100: low density lipoproteins with abnormal receptor binding. Proc Natl Acad Sci USA. 1987; 84(19):6919-23.

19. Innerarity TL, Mahley RW, Weisgraber KH, Bersot TP, Krauss R, Vega G, et al. Familial defective apolipoprotein B-100: a mutation of apolipoprotein B that causes hypercholesterolemia. J. Lipid Res. 1990; 31(8):1337-49.

20. Soutar A, Myant N, Thompson G. Simultaneous measurement of apolipoprotein B turnover in very-low-and low-density lipoproteins in familial hypercholesterolaemia. Atherosclerosis. 1977;28(3):247-56.

21. Schumaker VN, Phillips ML, Chatterton JE. Apolipoprotein B and low-density lipoprotein structure: implications for biosynthesis of triglyceriderich lipoproteins. Adv Protein Chem 1994; 45:205248.

22. Soria LF, Ludwig EH, Clarke H, Vega GL, Grundy SM, McCarthy BJ. Association between a specific apolipoprotein B mutation and familial defective apolipoprotein B-100. Proceedings of the National Academy of Sciences. 1989; 86(2):587-91.

23. Gaffney D, Reid JM, Cameron IM, Vass K, Caslake MJ, Shepherd J, et al. Independent mutations at codon 3500 of the apolipoprotein B gene are associated with hyperlipidemia. Arterioscler Thromb Vasc Biol. 1995; 15(8):1025-9.

24. Pullinger CR, Hennessy LK, Chatterton JE, Liu W, Love JA, Mendel CM, et al. Familial ligand-defective apolipoprotein $\mathrm{B}$. Identification of a new mutation that decreases LDL receptor binding affinity. J Clin Invest. 1995; 95(3):1225.

25. Abifadel M, Rabès JP, Jambart $S$, Halaby $G$, GannagéYared $\mathrm{MH}$, Sarkis $\mathrm{A}$, et al. The molecular basis of familial hypercholesterolemia in Lebanon: spectrum of LDLR mutations and role of PCSK9 as a modifier gene. Hum Mutat. 2009; 30(7):E682-E91.

26. Abifadel $M$, Varret $M$, Rabès J-P, Allard $D$, Ouguerram $\mathrm{K}$, Devillers $\mathrm{M}$, et al. Mutations in PCSK9 cause autosomal dominant hypercholesterolemia. Nat Genet. 2003; 34(2):154-6.

27. Maxwell KN, Breslow JL. Adenoviral-mediated expression of Pcsk9 in mice results in a low-density lipoprotein receptor knockout phenotype. Proc Natl Acad Sci USA. 2004; 101(18):7100-5. 
28. Cohen JC, Boerwinkle E, Mosley Jr TH, Hobbs $\mathrm{HH}$. Sequence variations in PCSK9, low LDL, and protection against coronary heart disease. $N$ Engl J Med. 2006; 354(12):1264-72.

29. Zende PD, Bankar MP, Kamble PS, Momin AA. Apolipoprotein e gene polymorphism and its effect on plasma lipids in arteriosclerosis. J Clin Diagn Res. $2013 ; 7(10): 2149-52$.

30. Eichner JE, Dunn ST, Perveen G, Thompson DM, Stewart KE, Stroehla BC. Apolipoprotein E polymorphism and cardiovascular disease: a huge review. Am J Epidemiol. 2002; 155(6):487-95.

31. Davignon J, Gregg RE, Sing CF. Apolipoprotein E polymorphism and atherosclerosis. Arterioscler Thromb Vasc Biol. 1988; 8(1):1-21.

32. Garcia CK, Wilund K, Arca M, Zuliani G, Fellin R, Maioli $\mathrm{M}$, et al. Autosomal recessive hypercholesterolaemia caused by mutations in a putative LDL receptor adaptor protein. Science 2001; 292:1394-8.

33. Arca M, Zuliani G, Wilund K, Campagna F, Fellin $\mathrm{R}$, Bertolini $\mathrm{S}$, et al. Autosomal recessive hypercholesterolaemia in Sardinia, Italy, and mutations in $\mathrm{ARH}$ : a clinical and molecular genetic analysis. The Lancet. 2002; 359(9309):841-7.

34. Rader DJ, Cohen J, Hobbs HH. Monogenic hypercholesterolemia: new insights in pathogenesis and treatment. J Clin Invest. 2003; 111(12):1795-803.

35. Huijgen R, Kindt I, Defesche JC, Kastelein JJ. Cardiovascular risk in relation to functionality of sequence variants in the gene coding for the lowdensity lipoprotein receptor: a study among 29 365 individuals tested for 64 specific low-density lipoprotein-receptor sequence variants. Eur Heart J. 2012; 33(18):2325-30.

36. Williams RR, Hunt SC, Schumacher MC, Hegele $\mathrm{RA}$, Leppert MF, Ludwig EH, et al. Diagnosing heterozygous familial hypercholesterolemia using new practical criteria validated by molecular genetics. Am J Cardiol. 1993; 72(2):171-6.

37. Betteridge D. Scientific Steering Committee on behalf of the Simon Broome Register Group. Mortality in treated heterozygous familial hypercholesterolaemia: implications for clinical management. Atherosclerosis. 1999; 142:105-12.

38. World Health Organization. Familial hypercholesterolaemia - report of a second WHO Consultation. Geneva, Switzerland: World Health Organization, 1999. (WHO publication no. WHO/ HGN/FH/CONS/99.2).

39. Brautbar A, Leary E, Rasmussen K, Wilson DP, Steiner RD, Virani S. Genetics of familial hypercholesterolemia. Curr Atheroscler Rep. 2015; 17(4):1-17.

40. Besseling J, Sjouke B, Kastelein JJ. Screening and treatment of familial hypercholesterolemia-Lessons from the past and opportunities for the future (based on the Anitschkow Lecture 2014). Atherosclerosis. 2015; 241(2):597-606.

41. Marks D, Thorogood $M$, Neil HAW, Wonderling D, Humphries SE. Comparing costs and benefits over a 10 year period of strategies for familial hypercholesterolaemia screening. J. Public Health. 2003;25(1):47-52.

42. Watts GF, Gidding S, Wierzbicki AS, et al. Integrated Guidance on the Care of Familial Hypercholesterolaemia from the International FH Foundation. Int J Cardiol. 2014; 171:309-325.

43. Harada-Shiba M, Arai H, Oikawa S, et al. Guidelines for the management of familial hypercholesterolemia. J Atheroscler Thromb. 2012; 19(12):1043-60.

44. Pang J, Sullivan DR, Harada-Shiba M, Ding PY, Selvey S, Ali S, Watts GF. Significant gaps in awareness of familial hypercholesterolaemia among physicians in selected Asia-Pacific countries: a pilot study. J Clin Lipidol. 2015; 9:42-8.

45. Mabuchi H, Nohara A, Noguchi T, Kobayashi J, Kawashiri $\mathrm{M}-\mathrm{a}$, Inoue T, et al. Genotypic and phenotypic features in homozygous familial hypercholesterolemia caused by proprotein convertase subtilisin/kexin type 9 (PCSK9) gain-of-function mutation. Atherosclerosis. 2014; 236(1):54-61.

46. Livy A, Lye SH. Familial hypercholesterolemia in Asia: a review. Journal of OMICS Research. 2011; 1(1):22-31.

47. Choong ML, Koay ES, Khoo KL, Khaw MC, Sethi SK. Denaturing gradient-gel electrophoresis screening of familial defective apolipoprotein B-100 in a mixed Asian cohort: two cases of arginine3500 $\rightarrow$ tryptophan mutation associated with a unique haplotype. Clin Chem. 1997; 43(6):916-23.

48. Khoo K, Van Acker P, Defesche J, Tan H, Van de Kerkhof L, Heijnen-van Eijk S, et al. Low-density lipoprotein receptor gene mutations in a Southeast Asian population with familial hypercholesterolemia. Clin Gene. 2000; 58(2):98-105.

49. Khoo K, Van Acker P, Tan H, Deslypere J. Genetic causes of familial hypercholesterolaemia in a Malaysian population. Med J Malaysia. 2000; 55(4):409-18.

50. Gudnason V, Day IN, Humphries SE. Effect on plasma lipid levels of different classes of mutations in the low-density lipoprotein receptor gene in patients with familial hypercholesterolaemia. Arterioscler Thromb. 1994;14:1717-22.

51. Azian M, Hapizah M, Khalid B, Khalid Y, Rosli A, Jamal $R$. Use of the denaturing gradient gel electrophoresis (DGGE) method for mutational screening of patients with familial hypercholesterolaemia (FH) and Familial defective apolipoprotein B100 (FDB). Malays J Pathol. 2006; 28(1):7-15.

52. Al-Khateeb A, Zahri MK, Mohamed MS, Sasongko TH, Ibrahim S, Yusof Z, et al. Analysis of sequence variations in low-density lipoprotein receptor gene among Malaysian patients with familial hypercholesterolemia. BMC Med Genet. 2011; 12(1):1.

53. Chiou KR, Charng MJ. Detection of mutations and large rearrangements of the low-density lipoprotein receptor gene in Taiwanese patients with familial hypercholesterolemia. Am J Cardiol. 2010; 105(12):1752-8. 
54. Chahil J, Lye S, Bagali P, Alex L. A novel pathogenic variant of the LDLR gene in the Asian population and its clinical correlation with familial hypercholesterolemia. Mol Biol Rep. 2012; 39(7):7831-8.

55. Jeon H, Meng W, Takagi J, Eck MJ, Springer TA, Blacklow SC. Implications for familial hypercholesterolemia from the structure of the LDL receptor YWTD-EGF domain pair. Nat Struct Mol Biol. 2001; 8(6):499-504.

56. Alex L, Chahil JK, Lye SH, Bagali P, Ler LW. Differences in allele frequencies of autosomal dominant hypercholesterolemia SNPs in the Malaysian population. J Hum Genet. 2012; 57(6):358-62.

57. Lye SH, Chahil JK, Bagali P, Alex L, Vadivelu J, Ahmad WAW, et al. Genetic polymorphisms in LDLR, APOB, PCSK9 and other lipid related genes associated with familial hypercholesterolemia in Malaysia. PloS one. 2013; 8(4):e60729.

58. Al-Khateeb AR, Mohd MS, Yusof Z, Zilfalil BA. Molecular description of familial defective APOB-100 in Malaysia. Biochem Genet. 2013; 51(9-10):811-23.

59. Al-Khateeb A, Al-Talib H, Mohamed MS, Yusof Z, Zilfalil BA. Phenotype-Genotype Analyses of Clinically Diagnosed Malaysian Familial Hypercholestrolemic Patients . Adv Clin Exp Med. 2013; 22(1):57-67.

60. Alicezah MK, Rahman T, Koshy M. Homozygous familial hypercholesterolemia. Malaysian J Pathol. 2014; 36(2):131.

61. Wang J, Huff E, Janecka L, Hegele RA. Low density lipoprotein receptor (LDLR) gene mutations in Canadian subjects with familial hypercholesterolemia, but not of French descent. Hum Mutat. 2001; 18(4):359.

62. Fahed AC, Safa RM, Haddad FF, Bitar FF, Andary RR, Arabi MT, et al. Homozygous familial hypercholesterolemia in Lebanon: a genotype/phenotype correlation. $\mathrm{Mol}$ Genet Metab. 2011; 102(2):181-8.

63. Bertolini $S$, Pisciotta L, Rabacchi $C$, Cefalù $A B$, Noto $D$, Fasano $T$, et al. Spectrum of mutations and phenotypic expression in patients with autosomal dominant hypercholesterolemia identified in Italy. Atherosclerosis. 2013; 227(2):342-8.

64. Taylor A, Wang D, Patel K, Whittall R, Wood G, Farrer $M$, et al. Mutation detection rate and spectrum in familial hypercholesterolaemia patients in the UK pilot cascade project. Clin Genet. 2010; 77(6):572-80.

65. Castro-Orós D, Pampín S, Bolado-Carrancio A, De Cubas A, Palacios L, Plana N, et al. Functional analysis of LDLR promoter and 5' UTR mutations in subjects with clinical diagnosis of familial hypercholesterolemia. Hum Mutat. 2011; 32(8):868-72.

66. Nelken J, Meshkani R, Chahal N, McCrindle B, Adeli K. Detection of familial defective apoB (FDB) mutations in hypercholesterolemic children and adolescents by denaturing high performance liquid chromatography (DHPLC). Clin Biochem. 2008; 41(6):395-9.

67. Mabuchi H, Nohara A, Noguchi T, Kobayashi J, Kawashiri $\mathrm{M}-\mathrm{a}$, Inoue T, et al. Genotypic and phenotypic features in homozygous familial hypercholesterolemia caused by proprotein convertase subtilisin/kexin type 9 (PCSK9) gain-of-function mutation. Atherosclerosis. 2014; 236(1):54-61.

68. Jelassi A, Najah M, Jguirim I, Maatouk F, Lestavel S, Laroussi $\mathrm{O}$, et al. A novel splice site mutation of the LDL receptor gene in a Tunisian hypercholesterolemic family. Clin Chim Acta. 2008; 392(1):25-9.

69. Sijbrands EJ, Westendorp RG, Lombardi MP, Havekes LM, Frants RR, Kastelein JJ, et al. Additional risk factors influence excess mortality in heterozygous familial hypercholesterolaemia. Atherosclerosis. 2000; 149(2):421-5.

70. Junyent M, Gilabert R, Jarauta E, Núñez I, Cofán M, Civeira F, et al. Impact of low-density lipoprotein receptor mutational class on carotid atherosclerosis in patients with familial hypercholesterolemia. Atherosclerosis. 2010; 208(2):437-41.

71. Hegele RA. Genetic susceptibility to heart disease in Canada: lessons from patients with familial hypercholesterolemia. Genome. 2006; 49(11):134350.

72. Alonso R, Mata N, Castillo S, Fuentes F, Saenz P, Muñiz $O$, et al. Cardiovascular disease in familial hypercholesterolaemia: influence of low-density lipoprotein receptor mutation type and classic risk factors. Atherosclerosis. 2008; 200(2):315-21. 